Article

\title{
Virus-Laden Particles and Particulate Matter (Air Pollutants) with Viruses Attached: How Rumors That Air Pollutants Spread SARS-CoV-2 Are Born ${ }^{\dagger}$
}

\author{
Alexander Ishmatov (D)
}

check for

updates

Citation: Ishmatov, A. Virus-Laden Particles and Particulate Matter (Air Pollutants) with Viruses Attached: How Rumors That Air Pollutants Spread SARS-CoV-2 Are Born Med. Sci. Forum 2021, 4, 21. https:// doi.org/10.3390/ECERPH-3-08982

Academic Editor: Zahid Ahmad Butt

Published: 11 January 2021

Publisher's Note: MDPI stays neutral with regard to jurisdictional claims in published maps and institutional affiliations.

Copyright: (C) 2021 by the author. Licensee MDPI, Basel, Switzerland. This article is an open access article distributed under the terms and conditions of the Creative Commons Attribution (CC BY) license (https:/ / creativecommons.org/licenses/by/ $4.0 /)$.
Institute of Engineering and Environmental Safety, Togliatti State University, Belorusskaya St. 14, 445020 Togliatti, Russia; ishmatoff@centercem.ru

+ Presented at the 3rd International Electronic Conference on Environmental Research and Public Health-Public Health Issues in the Context of the COVID-19 Pandemic, 11-25 January 2021; Available online: https:/ / ecerph-3.sciforum.net/.

\begin{abstract}
Premature and unsubstantiated claims that SARS-CoV-2 coagulates (creates clusters) with outdoor particulate matter (PM10) in the air and that SARS-CoV-2 can be transported by air pollutants became widely circulated in the media and have been cited by some studies as fact. Although the presence of the markers of SARS-CoV-2 (viral fragments of coronavirus) in environmental samples is an important finding, the media and researchers should be cautious regarding the claim that SARS-CoV-2 can create clusters with outdoor PM10 in the air and spread via particulate air pollution, as this statement is currently only a hypothesis that lacks direct or indirect supporting evidence.
\end{abstract}

Keywords: airborne transmission; air pollution; SARS-CoV-2; COVID-19; aerosol

In recent studies [1,2], Prof. Bontempi mentioned the problem of the lack of suitable terminology and confusion arising from the perception that the diffusion of airborne viruses can be promoted by outdoor sources (such as PM).

The study [3] of Setti et al. (May 2020) shows that the sampling and analysis of outdoor/airborne PM10 can be useful for detecting airborne RNA traces of SARS-CoV-2 and thus, identifying the presence of a potential viral hazard. This is an important finding and the method reported could be used to identify the early warning signs and scale of an outbreak. It is important to note that as the authors pointed out the limitation of this study, which is that the results did not demonstrate that SARS-CoV-2 was viable and infectious. However, one point in the text of the original paper may give the erroneous impression that SARS-CoV-2 is transported by air pollutants. An analysis of the data obtained by the authors and the literature cited by them in the text [3] shows that the conclusion that SARS-CoV-2 can create clusters with outdoor PM is unfounded and premature.

It is known that typical droplets generated by cough, sneeze or speech (e.g., $\mathrm{d}<20 \mu \mathrm{m})$ can be airborne and remain so for a long time [4]: " ... on initially $20 \mu \mathrm{m}$ droplets was provided which can linger in still air for $\left.20 \mathrm{~min}-1 \mathrm{~h}^{\prime \prime}\right)$. Air flows may carry such aerosols for long periods, although the duration depends on the context. This is true even without assuming droplet drying, and particularly true when drying is taken into account (drying strongly influences the airborne duration). The evaporation process completes instantaneously for small respiratory droplets with an initial size of less than $20 \mu \mathrm{m}$. These droplets evaporate rapidly to half of their initial size and become droplet nuclei [5]. Droplet nuclei are dry particles that may include viruses and other pathogens and tend to remain airborne; they thus could be distributed over a greater area than initial droplets.

As virus-laden droplet nuclei can be airborne, they could be collected in PM10 samples. However, it cannot be concluded from this fact that virus-laden particles create clusters with outdoor PM. Although such an "event" is possible, no direct evidence of such an event is provided by Setti et al. (2020) [3]. This is also true for all sources cited in their paper. To 
prove this, it is necessary to conduct a microscopic examination of the collected samples, which would show the clustering of virus-laden particles with outdoor PM. Microscopic examination of samples is a time-consuming and difficult task, and special measures are required when collecting samples (to exclude particle interaction post collection). Thus, from this point of view, virus-bearing aerosols from human atomization and virus-laden particles are not equivalent to particulate matter (air pollutants) with viruses attached.

As was rightly noted by professor Daniele Contini in a discussion on this matter (https: //www.researchgate.net/post/Any_association_between_air_quality_and_virus_spread? isAnswerFieldFocused $=$ true $\#$ view $=5$ ea1bd46c620916f1b3acc9c accessed on 20 September 2021): "Small droplets are released during respiration and speeches and these could evaporate (partly or totally leaving more or less dried residue) and they are sufficiently small to be suspended in atmosphere and transported/dispersed like the other particle. So, the question is why they should be "carried" by other particles in air? They will also be transported by themselves like any other particle." In addition, the results of the analysis of Bontempi $[2,3]$ show that it is not possible to demonstrate that air pollution can accelerate virus diffusion, and, moreover, the pandemic's diffusion patterns are typically caused by a multiplicity of environmental, economic and social factors. In fact, theoretical evidence is that it (that virus-laden particles create clusters with outdoor PM) cannot occur, even in pollution events due to a too low PM concentration which means a far too slow kinetic of coagulation as discussed in [6-8].

Unfortunately, unfounded speculations and conclusions related to the spreading of SARS-CoV-2 by air pollutants are increasingly appearing in newspapers and research articles (see full review in [9]).

The original study of Setti et al. (2020) [3] and other available studies (see full review in [9]) do not provide sufficient basis for the conclusions that SARS-CoV-2 creates clusters with outdoor PM and that the pollution particles are similar to "micro-airplanes" with the (respiratory) droplets being the "passengers." The analysis by Setti et al. (2020) [3] does not consider the possibility that virus-laden particles of different sizes $(<10 \mu \mathrm{m})$ can be collected from the air and these particles are not equivalent to particulate matter (air pollutants) with viruses attached. Thus, the data presented by Setti et al. (2020) [3] and other researchers (see full review in [9]) do not provide direct or indirect evidence of the creation of clusters of SARS-CoV-2 with outdoor PM.

Thus, there is great ambiguity in the definitions of essential concepts related to the relationship between air pollution and coronavirus, including the concepts of "air pollution as a factor for health risk" and "SARS-CoV-2 spread by particulate air pollution", and dispute over what constitute "virus-laden particles", "droplet nuclei", "virus-bearing aerosols produced from human atomization", and "particulate matter (air pollutants) with viruses attached". This ambiguity has resulted in deep misunderstandings between researchers and the spread of misinformation.

Although the presence of airborne SARS-CoV-2 in environmental samples is an important finding and its detection in such samples could serve as an early warning sign and indicate the scale of an outbreak, readers, researchers, and the media should be skeptical of the claims that SARS-CoV-2 can create clusters with outdoor PM and that SARS-CoV-2 can spread by particulate air pollution, as these are currently merely hypotheses that lack direct or indirect supporting evidence.

A full version of the paper [9], additional material and data on seasonality of enhanced deposition of inhaled aerosols and pollutants due to the effect of air supersaturation in the human airways as a factor of seasonality of respiratory infections (and probably of seasonality of COVID-19) can be found in [10-12].

Funding: This research was not funded by any organization or university and did not receive any specific grant from funding agencies in the public, commercial, or not-for-profit sectors.

Institutional Review Board Statement: Research not involved human subjects.

Informed Consent Statement: Research not involved human subjects. 
Data Availability Statement: Research not involved human subjects.

Acknowledgments: I thank ACS Authoring Services (American Chemical Society) for proofreading and editing the text and for giving me the opportunity to use the service without charging a fee; Alexandra Elbakyan for the providing rapid and hassle-free access to published scientific data; Anna Shandenkova for help in English translation. Finally, I thank David Williams (The Proof \& Edit Company, UK) for support and useful tips.

Conflicts of Interest: I report no competing interests.

\section{References}

1. Bontempi, E. Commercial exchanges instead of air pollution as possible origin of COVID-19 initial diffusion phase in Italy: More efforts are necessary to address interdisciplinary research. Environ. Res. 2020, 109775. [CrossRef] [PubMed]

2. Bontempi, E. First data analysis about possible COVID-19 virus airborne diffusion due to air particulate matter (PM): The case of Lombardy (Italy). Environ. Res. 2020, 186, 109639. [CrossRef] [PubMed]

3. Setti, L.; Passarini, F.; De Gennaro, G.; Barbieri, P.; Perrone, M.G.; Borelli, M.; Palmisani, J.; Di Gilio, A.; Torboli, V.; Fontana, F.; et al. SARS-Cov-2RNA Found on Particulate Matter of Bergamo in Northern Italy: First Evidence. Environ. Res. 2020, 109754. [CrossRef] [PubMed]

4. Vuorinen, V.; Aarnio, M.; Alava, M.J.; Alopaeus, V.; Atanasova, N.S.; Auvinen, M.; Balasubramanian, N.; Bordbar, H.; Erasto, P.; Grande, R.R.; et al. Modelling aerosol transport and virus exposure with numerical simulations in relation to SARS-CoV-2 transmission by inhalation indoors. arXiv 2020, arXiv:2005.12612v1. [CrossRef]

5. Nicas, M.; Nazaroff, W.W.; Hubbard, A. Toward understanding the risk of secondary airborne infection: Emission of respirable pathogens. J. Occup. Environ. Hyg. 2005, 2, 143. [CrossRef]

6. Rowe, B.R.; Canosa, A.; Drouffe, J.M.; Mitchell, J. Simple quantitative assessment of the outdoor versus indoor airborne transmission of viruses and 1324 COVID-19. Environ. Res. 2021, 198, 111189. [CrossRef] [PubMed]

7. Belosi, F.; Conte, M.; Gianelle, V.; Santachiara, G.; Contini, D. On the concentration of SARS-CoV-2 in outdoor air and the interaction with pre-existing atmospheric particles. Environ. Res. 2021, 193, 110603. [CrossRef] [PubMed]

8. Doussin, J.F. How Airborne Is the Virus? 2020. Available online: https://news.cnrs.fr/articles/how-airborne-is-the-virus (accessed on 20 September 2021).

9. Ishmatov, A. "SARS-CoV-2 is transmitted by particulate air pollution": Misinterpretations of statistical data, skewed citation practices, and misuse of specific terminology spreading the misconception. Environ. Res. 2021, 204 Pt B, 112116. [CrossRef] [PubMed]

10. Ishmatov, A. Age- and Gender-Related Changes in the Upper Airways, Which Lead to Increased Exposure of Lower Airways to Air Pollutants, Correlate with Deaths Involving COVID-19 in the United States in 2020: Short Report. 2020. Available online: https: / / ssrn.com/abstract=3697921 (accessed on 20 September 2021).

11. Ishmatov, A. Influence of weather and seasonal variations in temperature and humidity on supersaturation and enhanced deposition of submicron aerosols in the human respiratory tract. Atmos. Environ. 2020, 223, 117226. [CrossRef]

12. Ishmatov, A.N. Climatic conditions and supersaturation in the airways as a new factor for enhanced deposition of ambient aerosols: A pilot study. In Proceedings of the SPIE 11208, 25th International Symposium on Atmospheric and Ocean Optics: Atmospheric Physics, Novosibirsk, Russia, 18 December 2019; p. 112087H. 